\title{
Socio-economic factors influencing adoption of Moringa oleifera water purification by farmers in Kaduna state, Nigeria
}

\author{
A. S. Fadoyin, S. O. Oyewole, F. A. Ayanrinde, G. A. Baba, T. \\ Savanna Forestry Research Station, Samaru, Zaria, Nigeria
}

\section{ABSTRACT}

This study investigated those factors which influenced the option o

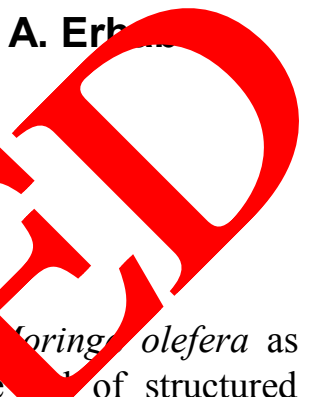
water purifier by the farmers in Kaduna state. Data were col $^{1}$ with the of structured questionnaire from 30 respondents. The data were analyzed ing a riptive statistics and logit regression model. The results showed that the respondents 1 ne form edycation or the other. About 90 percent were married average household size of 0 persons per hou. nold. About 73 percent adopted Moringa oleifera water purification. Socio-econ nic factors influencing adoption of Moringa oleifera water purification were age, education, extens contact an membership of cooperative. The study therefore recommends that farmers should for mselv s into association because such association will aid in collective soliciting f vernment assistance, NGOs and other funding agencies. Also, more awareness should be cre ea Moringa oleifera seed powder in rural developme

Keywords: Moringa olefera; adop on; waे r purifiel ocio-economic factors; extension agents

\section{INTRODUCTIC}

Moring oleife (Family.Moringaceae) is cultivated across the tropics and used for a variety of pu (Jahn 1986). Its seed powder is a good water purifier; and contains polyele mat ie se srom s and shrubs of Moringaceae family are effective in clarifying turbid anc. aste untar in/ropical countries (Jahn, 1986), especially during rainy season. Muyibi and E (1995) noted that M. oleifera seeds have been used in the treatment of hard water, and provo hat hardness removal efficiency of $M$. oleifera increased with increasing dosage. Moringa sced powder is a natural alternative to imported alum (aluminum sulphate, the conventional synthetic coagulant) used in purifying turbid water in fish culture enclosures (earthen ponds, farm dams and irrigation canals). It is obtainable locally at a fraction of the cost of alum in many countries, simple to use and cheap to maintain (Jahn, 1986; Ndabigengesere and Nasarasiah, 1998). 


\section{METHODOLOGY}

\section{1. Study area}

The study was carried out in Bomo village, Sabon gari local government area, located between latitude $11811^{\circ}$ north and longitude $07038^{\circ}$ East at 675 meters. The hottest months are March-April, while the coldest months are December-January. Rainfall is heaviest in the south and decreases northwards with an annual mean rainfall varying between $942 \mathrm{~mm}$ and $1000 \mathrm{~mm}$ which last for six months (May-October) (NARERLS, 2002). Soil of the area is characterised by ferrogenous tropical soils formed on drift material (Klinkenbero and Haggins, 1968).

The surface soil is fine sandy loam, prone to capping and poor structy Its physi structure has been described by Kowal (1972). In this area trees like sea hutter cust be predominate, while in the north and northwest, Baobab, silk cotton and date $1 \mathrm{~m}$ re predominant. The people in this area engage in agricultural producti actio ies. Th nain crops which are grown include maize, millet, rice, groundnut, yam na cane.

Primary data were used for this study. These were collect d with aid of structured questionnaire. The data were collected from 30 respondents

\section{2. Analytical techniques}

Descriptive statistics: this was used to describ socio-economic/characteristics of the farmers and level of adoption. It includes frequency unt and per fentages.

Logit regression: this was used to identify sod and institutional factors influencing adoption of Moringa oleifera $\mathrm{m}$ urification. The probability of a respondents adopting Moringa oleifera purification is det rmin underlying response variable that captures the true socio-economic status of the spond nnts. The underlying response variable $\mathrm{y}^{*}$ in the case of binary choice is ach by the nultivariate logit regression relation:$$
x i \beta j)+\mu
$$

where: $\beta_{\mathrm{j}}=\beta_{1}, \beta_{2}, \beta_{3}$ o4, $\beta_{6}, \beta_{7}, \beta_{8}$, nd $X_{i}=X_{i 1}, X_{i 2}, X_{i 3}, X_{i 4}, X_{i 5}, X_{i 6}, X_{i 7}, X_{i 8}$

The relevan ${ }^{+1} \rho_{g}$ istic $e$ ssions are given as:

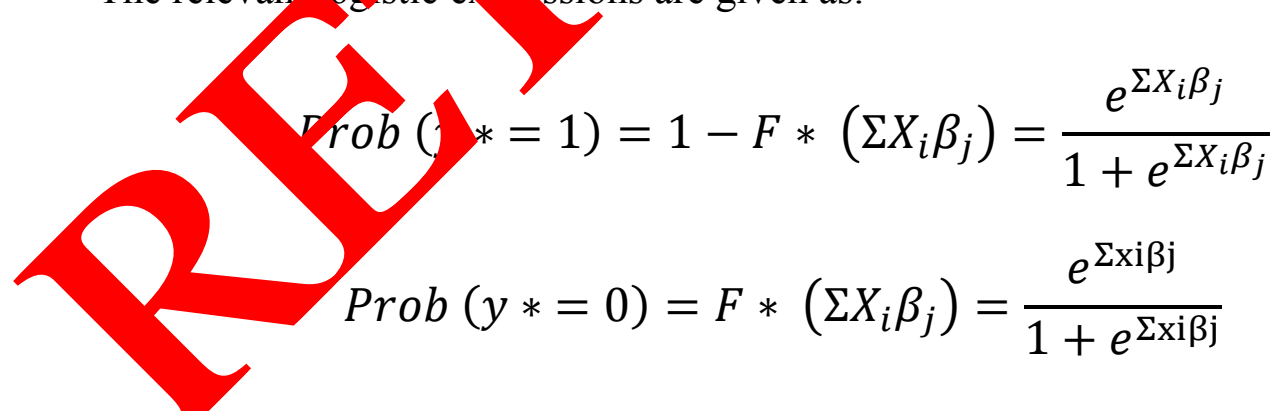

where: $\mathrm{F}=$ The cumulative distribution function for $\mu_{\mathrm{i}, \ldots}$

$\operatorname{Prob}\left(Y_{i}=\frac{0}{\beta j} X_{i}\right)=F\left(-\sum X_{i} \beta_{j}\right), \quad \operatorname{Prob}\left(Y_{i}=\frac{1}{\beta_{j}} X_{i}\right)=1-F\left(-\sum X_{i} \beta_{j}\right)$

where;

$\mathrm{Y}=\operatorname{adoption}(1=$ adopter, $0=$ non-adopter $)$

$\mu_{\mathrm{i}}=$ a logistic cumulative distribution in $\mathrm{F}$ 
$\mathrm{X}_{\mathrm{i}}=$ characteristics of households

$\mathrm{X}_{1}=$ Age

$\mathrm{X}_{2}=$ Education (years of formal schooling)

$\mathrm{X}_{3}=$ Household size (number of persons in the household)

$\mathrm{X}_{4}=$ Amount of credit received (Naira)

$\mathrm{X}_{5}=$ Membership of cooperative (years)

$\mathrm{X}_{6}=$ Income (Naira)

$\mathrm{X}_{7}=$ Extension contact (Number of contacts)

$\beta_{\mathrm{i}}=$ The coefficients for the respective variables in the logit function

\section{RESULTS AND DISCUSSION}

Results in Table 1 shows that Moringa olefeira activities are edom ted b Male; this may be due to religious belief, that men are more involved in ric c than $t$ women in the area. Table 1 further reveals household size between 1217 has pu ntag of (36.7), this implies that household have positive significant role 1 ving acti cs. Therefore, adoption of Moringa olefeira as water purifier is higher an ng th rge household than the small-sized household. This may be due to the fact th a rumers wh ge household have many families to carter for. Ninety percent of the re ondents were morried men while $10 \%$ were single. This shows the business as that of ttled minds and that it contributes to household economic stability in one way or the ther, Amlechi (2000). Most of the respondents (43.3\%) had Arabic education $26.7 \%$ ondary education, $13.3 \%$ had primary education, $10 \%$ had tertiary educa hile $6.7 \%$ only had no formal education. $95 \%$ of them are literates and had one forn of cum or the other. Education may not prerequisite to enter into Moringa buciness, bu their productivity could be enhanced by some level of educational attainmer. So nty thr epercent of the respondents adopted the innovation, while $26.6 \% \mathrm{di}$ as int the tochnology. The reason for relatively greater

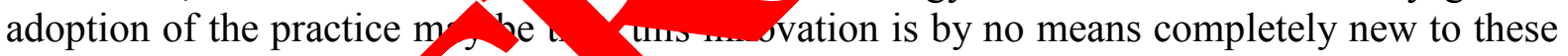
farmers. Studies (Roger 1965; an inberger, 1962) have also shown that are compatible with local practices a $\mathrm{k}$, n to be ao eptable to farmers.

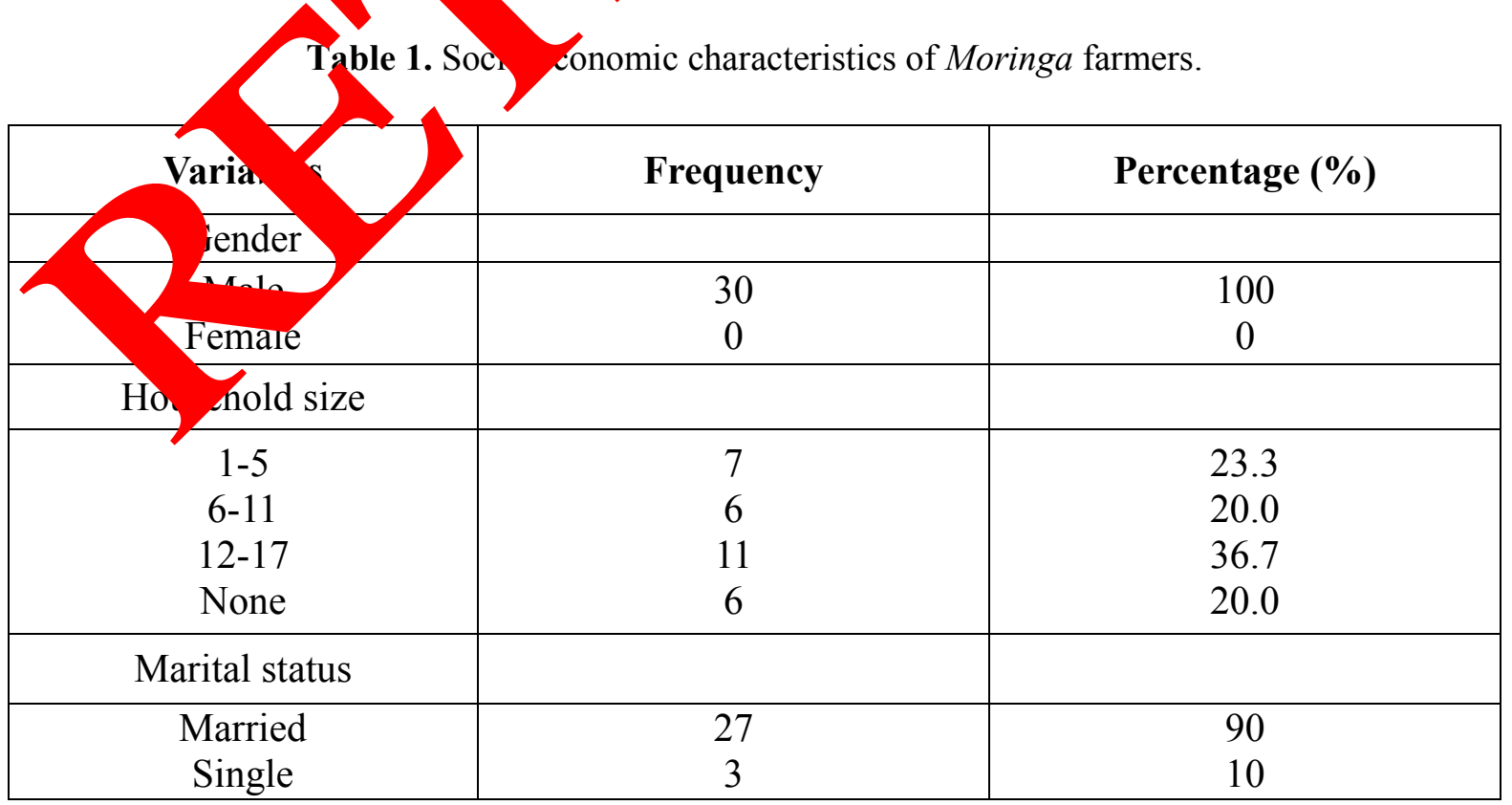




\begin{tabular}{|c|c|c|}
\hline Educational level & & \\
\hline Primary & 4 & 13.3 \\
Secondary & 8 & 26.7 \\
Tertiary & 3 & 10 \\
Arabic & 13 & 43.3 \\
Other & 2 & 6.7 \\
\hline
\end{tabular}

\section{1. Adoption of Moringa oleifera seed powder}

One of the objectives of the study was to determine the extent to which mers ha adopted the technology. Table 2 showed that, 73.4 percent adopted the ccmolog. nd 26.6 did not adopt the new technology. The reason for greater adoption of th techn oy is because; this practice is economical and environmental friendly o se armer studies (Rogers, 1965; and Lionberger, 1962)

Table 2. Adoption level of the teck $6 \log$

\begin{tabular}{|c|c|c|}
\hline Variables & Frequency & Pe centage \\
\hline Adopters & 22 & 73.4 \\
\hline Non-adopters & & 26.6 \\
\hline Total & & 100 \\
\hline
\end{tabular}

\section{2. Factors influencing adop oleifera seed powder}

Results presente Table 3 the factors that influence the adoption of Moringa oleifera in the study rea. vas reveared that four out of the seven variables included in the model were sig yariables were age, education, extension contact and membership coop rative. Ag was positive and significantly influential to the adoption of Moringa a a urification. This implied that as farmers increase in age the probability of a ting th method would also increase. The importance of age lies in its effect an adop innovations and the processing of information. This is evident that the is a sitive re cronship between age and adoption behaviour of farmers. Older farmers are adopt innovation than younger farmers. The coefficient obtained for educat is positive and significant at 5 percent level. This implies that the higher the education vel, the more the probability that respondents would adopt this method of water purification and vice versa, this is because education enhances the level of understanding. Also, the more educated a farmer, the more the chances that he/she would utilize available opportunity and adopt innovation.

The coefficient obtained for extension contact was positive and significant at 1 percent. The implication of this is that if farmers have more contact with the extension agent. There is probability that adoption would increase. This implied that availability of extension services and information about Moringa production as well as its utilization as water purification play important role in determining level of adoption. The coefficient $(0.447)$ for membership of 
associations was positive and significant at $5 \%$ level of probability. Membership of association can provide means of interaction with other farmers and this can also provide avenue or forum through which innovation can be diffused among farmers. Membership of association affords the farmers the opportunity of sharing information on modern farming practices by interacting with other farmers.

Table 3. Factors influencing adoption of Moringa oleifera seed powder.

\begin{tabular}{|c|c|c|c|}
\hline Variable & Coefficient & Standard error & \\
\hline Age & 0.063 & 0.028 & \\
\hline Education & 0.432 & 0.142 & \\
\hline Household size & -0.251 & & \\
\hline Amount of credit received & 0.472 & & \\
\hline Membership of cooperative & 0.573 & & $3.846^{* * *}$ \\
\hline Income & 0.015 & & 0.238 \\
\hline Extension contact & 0.171 & 0.023 & $7.434 * * *$ \\
\hline$* * *=\mathrm{P}<0.01 \quad * *=\mathrm{P}<0.05$ & $<0.10$ & & \\
\hline
\end{tabular}

The result of this finding cveal that, on anising the Moringa farmers into association is an essential task as it makeo wo ancier Also, such an association will aid in collective bargaining, soliciting go amen ssistance, Non Governmental Organisations and other funding agencies. Gen $1 \mathrm{y}$ Moring laifera seed powder can fit in rural development if modernize, as it is a ouro income nd nutrition and is not detrimental to the environment. Also, adequate at tron sho be paid to farmers' socio-economic characteristics as these would be signi, cant facilitators adoption of Moringa oleifera water purification. Extension agents shoy tro and the understand the socio-economic characteristics of farmers which influence their 1 of ado tion.

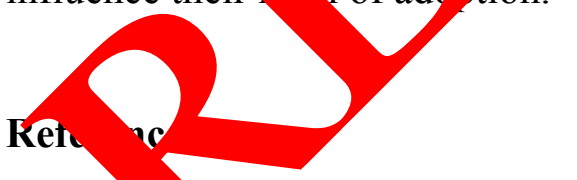

[1] Ameà R. O. (2000). Processing and marketing of Charcoal in Shaki East Local Government Area and in Ibadan Metropolis, Oyo State. An Unpublished Higher National Diploma Project Work, Federal College of Forestry, Ibadan. Pp 47 Centre For Agricultural development (CAD) (1991): Wood For Energy in Nigeria. 29:32-33.

[2] Jahn S. A. A., Jahn Samia-Al Azh-Aria, Al-Azharia J. S. (1986).Water treatment with traditional plant coagulant and clarifying Clay. Record 10 and 26 CAB Abstract 1987-1989.

[3] Jahn S. A. A., Journal of Analytical Science 1 (1986) 40-41. 
[4] Klinkenberg K., Higgins G. M. (1998). An Outline of Northern Nigerian Soils Issue 107 of Samaru research bulletin, Ahmadu Bello University. Institute for Agricultural Research and Special Services.

[5] Kowal and Knabe (1972). An agroclimatical Atlas of Northern States of Nigeria with explanatory notes. Ahmadu Bello University Press. ABU, Samaru Zaria Nigeria, p. 117.

[6] Muyibi S. A., Evison L. M., Water Research 29(4) (1995) 1099-1105.

[7] NAERLS (2002). "MAIZE extention Recommended Practices" EXTENSION No.3 NAERLS/ABU, Zaria, Nigeria.

[8] Ndabigengesere A., Narasiahk C., Water Resources 32 (1998) 781-791

[9] Rogers E. M. (1965). Diffusion of Innovation. Glecoe: Free press: 0612628434.

[10] Lionberger H. F. (1992). Adoption of New Ideas and Practi es. Am Iowa S ate University Press.

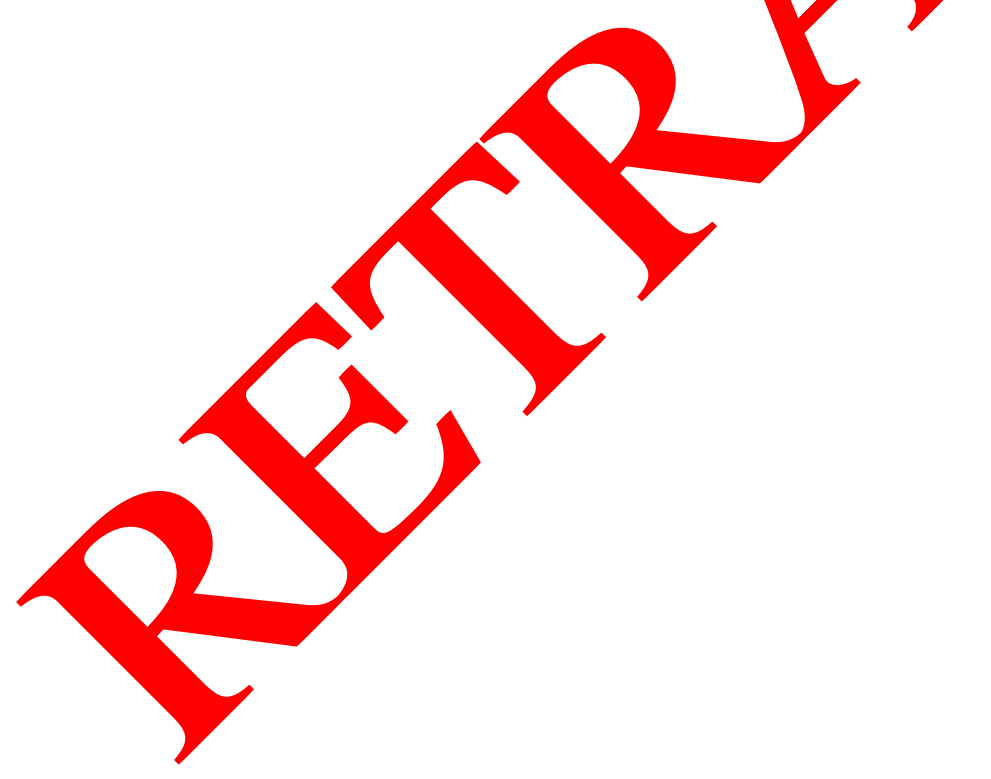

